\title{
Impact of inorganic powder additives on the size and morphology of pellets of the microscopic filamentous fungus Aspergillus niger
}

\author{
Sanja Nosalj1, ${ }^{1,}$, Karol Jesenák ${ }^{2}$, Alexandra Šimonovičová ${ }^{1}$, Pavol Hudec ${ }^{3}$ \\ ${ }^{1}$ Faculty of Natural Sciences, Department of Soil Science, Comenius University in Bratislava, Ilkovičova 6, Bratislava 84215, \\ Slovak Republic, \\ ${ }^{2}$ Faculty of Natural Sciences, Department of Anorganic chemistry, Comenius University in Bratislava, Ilkovičova 6, Bratislava \\ 84215, Slovak Republic, \\ ${ }^{3}$ Faculty of Chemical and Food Technology, Institute of Organic Chemistry, Catalysis and Petrochemistry, Slovak University \\ of Technology Radlinského 9, Bratislava 31237, Slovak Republic
}

$\triangle$ Corresponding author: nosalova15@uniba.sk

\section{Article info}

\section{Article history:}

Received: $14^{\text {th }}$ January 2021

Accepted: $21^{\text {st }}$ April 2021

\section{Keywords:}

Aspergillus niger

$\mathrm{Fe}_{2} \mathrm{O}$

Microscopic filamentous fungi

Montmorillonite

Size of pellets

$\mathrm{SiO}_{2}$

$\mathrm{TiO}_{2}$

Zeolites

\begin{abstract}
This paper has been focused on the impact of the set of microcrystal water-insoluble inorganic additives to dimension characteristics of pellets of the microscopic filamentous fungus Aspergillus niger. The selection of powder substances included montmorillonite clay mineral, silicon dioxide, iron oxide, one zeolitic tuff with mineral clinoptilolite as its main component, three synthetic zeolites, Na-mordenite, $\mathrm{NaY}$ and Na-ZSM-5, and titanium dioxide. This group is comprised of substances that are often components of various natural waters (including contaminated waters) and also frequent components of soil. Exceptions are synthetic zeolites and titanium dioxide. The impact of aforementioned substances was monitored on four Aspergillus niger strains isolated from soils at four Slovak locations, markedly differing in soil reaction values. Three of these soil samples have been affected by considerable contamination due to previous mining activities. Clay mineral montmorillonite reduced the size of the pellets regardless of the origin of strains, while the impact of other inorganic substances was either weak or variable depending on the type of inorganic substance and source location of the strains. The impact of natural zeolitic tuff was also similar, however, less significant.
\end{abstract}

\section{Introduction}

Microscopic filamentous fungi are widely used, particularly in the pharmaceutical and food industries. The ability of microscopic filamentous fungi to absorb harmful components from the surrounding environment, including toxic metals in various forms, is also used for the decontamination of various liquid substrates (Kapoor et al. 1999; Žemberyová et al. 2010; Ouyang et al. 2015). The most industrial applications of microscopic filamentous fungi use their biomass in the form of small pellets (Krull et al. 2013; Prajapati et al. 2014).

The growth and final size of the pellets as well as their morphology is affected by various factors. Some of the factors include the composition of the culture medium, its temperature and $\mathrm{pH}$ as well as the turbulence intensity of the liquid content of culture vessels or reactors. In the majority of cases, it is not only liquid solutions that are processed by biotechnological purifying methods, but also suspensions containing various small insoluble 
particles of different shapes and sizes. Such substances are not necessarily the original component of contaminated solutions; they may be added to the contaminated waters for the purpose of enhancing their purifying effect which is caused by sorption on the internal and external surfaces of these particles.

The intentional addition of various inorganic powders in culture media used for the biotechnological production of various substances is different. It has been established that the effectiveness of these technologies is influenced by the morphology of the microscopic filamentous fungi pellets (Znidarsič and Pavko 2001; Veiter et al. 2018; Shmedider et al. 2019). This knowledge is used in the production of substances such as itaconic acid, citric acid (Metz 1976) and certain enzymes and antibiotics (Papagianni et al. 2006; Teng et al. 2009). The first example of the utilization of inorganic powders in biotechnological productions was aluminum oxide and talc powder (hydrous magnesium silicate), which were used to increase the production of chloroperoxidase (Znidarsič and Pavko 2001). These substances facilitate the separation of individual fungi filaments, which improves their mutual contact with the surrounding solution. Driouch et al. (2012) studied in greater detail the optimization of the morphology of pellets of microscopic filamentous fungi Aspergillus niger for the production of enzymes.

Despite the existence of several works dealing with the effect of small inorganic particles on the morphology of the aforementioned fungi in complex systems, the question still remains how such particles affect the growth of the pellets in simple systems containing only a culture medium. Except for the works focusing on the effect of certain clay minerals such as kaolinite, bentonite and palygorskite, relatively little attention has been paid to this topic (Fomina and Gadd 2002). The general conclusion is that these minerals decrease the size of these pellets. The relation between the dimensional and morphological parameters of pellets and their ability to accumulate various soluble components is not quite clear. In connection with the decontamination of waters, it is almost certainly possible to reject the claim that there is no close relationship between them.
This paper strives to clarify the impact of certain inorganic microcrystal substances have on the dimensions and morphological qualities of pellets of the microscopic filamentous fungi Aspergillus niger. The selection of powders included montmorillonite clay mineral, silicon dioxide, iron oxide, one natural zeolite, three synthetic zeolites, and titanium dioxide. This group is comprised of substances which are often components of various natural waters (including contaminated waters); they are also soil components. Synthetic zeolites and titanium dioxide, that are due to their wide use (especially as a white pigment) among one of the industrial contaminants and despite this fact are safe to use, make an exception in this set. The common characteristics of all of the aforementioned substances is their considerable interactive surface which arises from the small size of their particles $\left(\mathrm{Fe}_{2} \mathrm{O}_{3}, \mathrm{SiO}_{2}\right.$, montmorillonite) or (also) their internal porous structure (zeolites and montmorillonite). The impact of these substances was monitored on four Aspergillus niger strains that were isolated from soil at four Slovak locations markedly differing in soil reaction values. Three of these soils have been affected by considerable contamination due to previous mining activities.

\section{Experimental}

\section{Fungal strains}

The Aspergillus niger strains were isolated from four locations whose soil reactions ranged from $\mathrm{pH}$ 3 (ultra acid) up to $\mathrm{pH} 9$ (strongly alkaline soil environments) (Črlík et al. 2003). The first strain, marked as $\mathrm{An}-\breve{\mathrm{S}}$, was isolated from the mine region of Šobov near Banská Štiavnica. The type of soil was Dystric Cambisol (contaminated and eroded) without vegetation and with high aluminum and iron content. Soil reaction was ultra acidic (pH 3.0). The second strain, marked as An $P$, was isolated from the stream sediment of the Blatina River in the environmentally burdened region of Pezinok with arsenic content $\left(363 \mathrm{mg} . \mathrm{kg}^{-}\right.$ $\left.{ }^{1}\right)$ and antimony content $\left(93 \mathrm{~g} \cdot \mathrm{kg}^{-1}\right)$. Soil reaction of these sediments was strong acidic ( $\mathrm{pH} \mathrm{5.3).} \mathrm{The}$ third strain came from the region Slovinky and was marked as An - Sl. The type of soil was Alkaline 
Technosol with medium alkali soil reaction $(\mathrm{pH}$ 8.3). The fourth strain, marked as An - G, was as a control strain and was isolated from the region of Gabčíkovo. The soil type was Eutric Fluvisol without any contamination. The soil reaction was slightly alkaline ( $\mathrm{pH}$ 7.7) (Šimonovičová et al. 2013; 2019).

\section{Pellet cultivation}

The pellets were prepared by adding $5 \mathrm{~mL}$ of conidia water suspension from the stock solution in $45 \mathrm{~mL}$ of a SDB medium culture (Sabouraud Dextrose Broth Liquid Medium, Himedia, Mumbai, India). One gram of powder substance was then added to the medium culture. Cultivation took place over 5 days at $25{ }^{\circ} \mathrm{C}$ in $250 \mathrm{~mL}$ Erlenmayer flasks placed with stirring at $135 \mathrm{rpm}$. (Unimax 2010 shaker, Heidolph, Germany). After the completion of the experiment, the microscopic filamentous fungi Aspergillus niger pellets were removed by filtration, washed with distilled water and placed in Petri dishes.

\section{Establishing pellet size}

The size of the pellets was established in a medium culture in transparent Petri dishes. Depending on their size, the number of pellets in the dish varied from 3 to 1,000 in the case of the smallest pellets. In all cases, the entire weight share of biomass represented by the microscopic filamentous fungi was cumulated in pellets. The size of the pellets was determined using a photographic recording complemented by a right-angle line raster with a known distance between the lines without using image analysis software (Fig. 1).

\section{Characteristics of powder forms}

Fine iron oxide and silicone dioxide powder with particles smaller than one micrometer was used in the experiments. Both chemicals were supplied by Sigma- Aldrich. The purity of both chemicals was in the p. a. category. Fine iron (III) oxide (SigmaAldrich, purity $>97.0 \%$ ) and silicone dioxide powder (Sigma-Aldrich, purity $\sim 99.0 \%$ ) with particles smaller than one micrometer was used in the experiments.

\section{Zeolites}

Three types of synthetic zeolites were used: Namordenite $\quad\left(\mathrm{SiO}_{2} / \mathrm{Al}_{2} \mathrm{O}_{3}=17.5\right), \quad \mathrm{NaY}$ $\left(\mathrm{SiO}_{2} / \mathrm{Al}_{2} \mathrm{O}_{3}=4.5\right) \quad$ and Na-ZSM-5 $\left(\mathrm{SiO}_{2} / \mathrm{Al}_{2} \mathrm{O}_{3}=28.5\right)$ and one natural clinoptilolite. Zeolites was used in the form of fine powder with a particle size of less than 5 micrometers.

Synthetic zeolites $\mathrm{NaY}$, NaM (mordenite) and NaZSM-5 were prepared in the Research Institute for Petroleum and Hydrocarbon Gases in Bratislava. Clinoptilolite was a natural zeolite from East-Slovakia deposits near Nižný Hrabovec. Clinoptilolite has chemical composition $\left(\mathrm{Ca}, \mathrm{K}_{2}\right.$, $\left.\mathrm{Na}_{2}, \mathrm{Mg}\right)_{4} \mathrm{Al}_{8} \mathrm{Si}_{40} \mathrm{O}_{96} \cdot 24 \mathrm{H}_{2} \mathrm{O}$ and contains about 84 $\%$ of clinoptilolite, $8 \%$ of crystobalite, $4 \%$ of illite, and $3-4 \%$ of plagioclase. More detailed characteristics of this rock are presented by Holub et al. (2016).

Textural properties of zeolites were determined by physical adsorption of nitrogen at the temperature of liquid nitrogen $\left(-196^{\circ} \mathrm{C}\right)$ using equipment ASAP 2400 (Micromeritics). Before measuring, samples were degassed in measuring burettes at $350{ }^{\circ} \mathrm{C}$ and vacuum of $2 \mathrm{~Pa}$ overnight. Textural properties of clinoptilolite as well as all synthetic zeolites are in Table 1.

Table 1. Textural properties of zeolites.

\begin{tabular}{lccccc}
\hline & $\begin{array}{c}\text { SBET } \\
{\left[\mathbf{m}^{\mathbf{2}} \cdot \mathbf{g}^{-\mathbf{1}}\right]}\end{array}$ & $\begin{array}{c}\mathbf{V}_{\text {micro }} \\
{\left[\mathbf{c m}^{\mathbf{3}} \cdot \mathbf{g}^{-\mathbf{1}}\right]}\end{array}$ & $\begin{array}{c}\mathbf{S}_{\mathbf{t}} \\
{\left[\mathbf{m}^{\mathbf{2}} \cdot \mathbf{g}^{-\mathbf{1}}\right]}\end{array}$ & $\begin{array}{c}\mathbf{V}_{\mathbf{a}} \\
{\left[\mathbf{c m}^{\mathbf{3}} \cdot \mathbf{g}^{-\mathbf{1}}\right]}\end{array}$ & $\begin{array}{c}\mathbf{D}_{\mathbf{p}} \\
{\left[\mathbf{n m}^{-}\right]}\end{array}$ \\
\hline $\mathrm{NaM}$ & 360 & 0.147 & 42.9 & 0.182 & - \\
$\mathrm{NaY}$ & 668 & 0.332 & 38.1 & 0.384 & - \\
$\mathrm{NaZSM-5}$ & 285 & 0.128 & 40.7 & 0.217 & - \\
clinoptilolite & 30.6 & 0.003 & 24.0 & 0.153 & 15,38 \\
\hline
\end{tabular}

$\mathrm{S}_{\mathrm{BET}}$ - specific surface area; $\mathrm{V}_{\text {micro }}$ - specific volume of micropores; $\mathrm{S}_{\mathrm{t}}$ - external surface size; $\mathrm{V}_{\mathrm{a}}-$ total pore volume; $\mathrm{D}_{\mathrm{p}}-$ size distribution of mesopores. 
Adsorption isotherms of all synthetic zeolites are typical for microporous materials - wide horizontal plateau on adsorption isotherms representing adsorption on external surface of zeolite crystals without any hystheresis loop ( $\mathrm{NaY}$ ) or with very narrow horizontal hystheresis loops (NaM, NaZSM-5) representing voids among tiny zeolite microcrystals (Fig. 1). Adsorption isotherm of clinoptilolite shows wide hystheresis loop corresponding to relatively great volume of mesopores and even partially macropores.

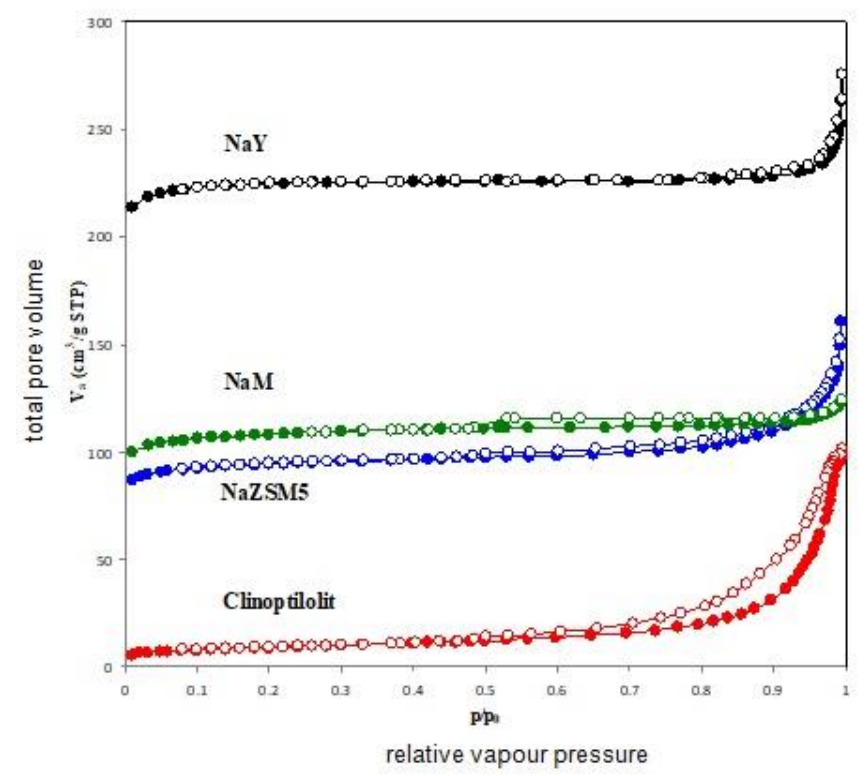

Fig. 1. Adsorption isotherms of zeolite samples.

Specific surface area $\mathrm{S}_{\mathrm{BET}}$ was calculated by treatment of adsorption data by BET-isotherm in the standard range of $\mathrm{p} / \mathrm{p}_{0}=0.05-0.30$. Specific volume of micropores $\mathrm{V}_{\text {micro }}$ and specific surface area of mesopores + external surface $S_{t}$ was calculated by t-plot method using Harkins-Jura standard isotherm. Total pore volume $\mathrm{V}_{\mathrm{a}}$ was estimated from data of adsorption isotherm at relative pressure of about $\mathrm{p} / \mathrm{p}_{0}=0.99$. Pore size distribution of mesopores $D_{p}$ was determined from desorption part of isotherm by standard $\mathrm{BJH}$ (Barett-Joyner-Halenda) method.

The highest specific surface area $\mathrm{S}_{\mathrm{BET}}$ was determined for $\mathrm{NaY}$ zeolite (almost $670 \mathrm{~m}^{2} / \mathrm{g}$ ), then for mordenite NaM $\left(360 \mathrm{~m}^{2} . \mathrm{g}^{-1}\right)$ and for NaZSM-5 zeolite $285 \mathrm{~m}^{2} \cdot \mathrm{g}^{-1}$. As it is seen from Table 1, from these values only about $38-43 \mathrm{~m}^{2} \cdot \mathrm{g}^{-1}$ was a real surface determined by t-plot ( $\mathrm{S}_{\mathrm{BET}}$ values have not physical meanings for microporous materials), and nitrogen was adsorbed predominantly in micropores $\left(0.332 \mathrm{~cm}^{3} \cdot \mathrm{g}^{-1}\right.$ for $\mathrm{NaY}, 0.147$ for $\mathrm{NaM}$ and 0.128 for NaZSM-5). On the other hand, clinoptilolit had quite low specific surface area $S_{\mathrm{BE}}$ - only $30.6 \mathrm{~m}^{2} \cdot \mathrm{g}^{-1}$ and only negligible volume of micropores $\mathrm{V}_{\text {micro }}=0.003 \mathrm{~cm}^{3} \cdot \mathrm{g}^{-1}$.

Synthetic zeolite samples are represented by crystals of pure zeolites, and contain only micropores and external surface of crystals. Clinoptilolite contained a wide range of mesopores between $5 \mathrm{~nm}$ and $50 \mathrm{~nm}$ (over $50 \mathrm{~nm}$ are already mesopores) with two observable maximums at 15 and $38 \mathrm{~nm}$ (Fig. 1). Peak at about $\mathrm{D}_{\mathrm{p}}=3.8 \mathrm{~nm}$ was an artifact that does not correspond to real pores. The characteristics of the zeolite channels are shown in Table 2.

Table 2. Channel characteristics of zeolites used.

\begin{tabular}{ll}
\hline zeolite & $\begin{array}{l}\text { Channel system } \\
{[\mathbf{n m}]}\end{array}$ \\
\hline $\mathrm{NaM}$ & $0.65 \times 0.70 ; 0.34 \times 0.48 ; 0.26 \times 0.57$ \\
$\mathrm{NaY}$ & $0.74 \times 0.74$ \\
$\mathrm{NaZSM}-5$ & $0.51 \times 0.55 ; 0.53 \times 0.56$ \\
clinoptilolite & $0.31 \times 0.75 ; 0.36 \times 0.46 ; 0.28 \times 0.47$ \\
\hline
\end{tabular}

\section{Clay mineral}

The montmorillonite used in this study was acquired by the sedimentation method from a $4 \%$ water bentonite suspension from the most famous Slovak location Stará Kremnička - Jelšový Potok (Slovak Republic). The bentonite from this location contains calcium-magnesium montmorillonite. A detailed description of the separation method provided Jesenák (1994) and Jesenák and Hlavatý (2000). The greater portion of montmorillonite particles was smaller than $2 \mu \mathrm{m}$. Specific surface area $S_{\text {BET }}$ was $112 \mathrm{~m}^{2} \cdot \mathrm{g}^{-1}$ and ethylene glycol specific surface area was $653 \mathrm{~m}^{2} \cdot \mathrm{g}^{-1}$.

\section{Results and Discussion}

Fungal pellets, which have the advantages of harvest ease, low fermentation broth viscosity and high yield of some proteins, have been used for a long time (Zhang and Zhang 2015). A wide range of microorganisms in the form of pellets have also significant application in environmental biotechnology for removal of heavy metals and 
toxic elements from various substrates (Fawzy et al. 2017). For example, bioaccumulation of some toxic metals by association of $A$. niger fungal pellets and green algae Chlorella vulgaris has been confirmed in many experiments (Šimonovičová et al. 2018; Remenárová et al. 2020).

Aspergillus niger strains used in this study differ in the source of origin and also in characteristics such as growth rate and sporulation, production of organic acids and enzymes (Šimonovičová et al. 2017; Nosalj and Šimonovičová 2019; Šimonovičová et al. 2020). Against this background we also assumed the variability in the formation of pellets. It was also confirmed during the cultivation in the SDB solution without added inorganic powders (Fig. 2; Fig. 3).
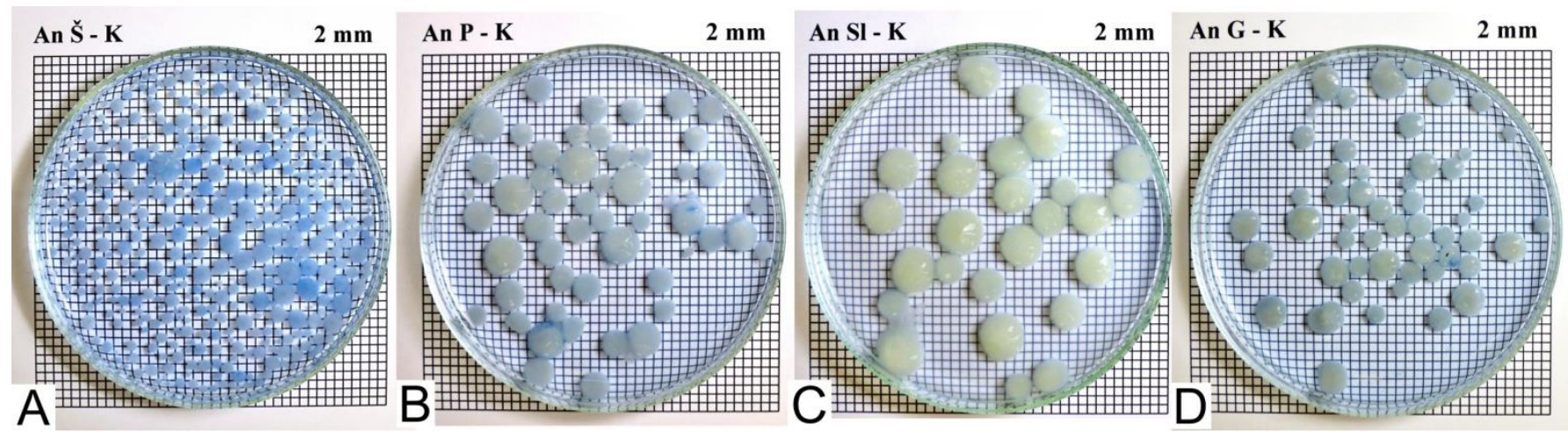

Fig. 2. Shots of pellets of microscopic filamentous fungi A. niger cultivated in an SDB solution without added inorganic powders as a control $(\mathrm{K})$. The shots illustrate a marked variation in the size of pellets acquired from conidia of microscopic filamentous fungi isolated from soils from various environments. A - An Š (strain isolated from the locality Šobov), B - An P (strain isolated from the locality Pezinok), C - An Sl (strain isolated from the locality Slovinky) and D - An G (strain isolated from the locality Gabčíkovo).

Fig. 3 also indicates the sizes of pellets acquired through the cultivation of the aforementioned strains without any additional inorganic powders. The variance of average values of $A$. niger pellets that were prepared from conidia of microscopic filamentous fungi originated from the soils from various environments and cultivated without the presence of powder microparticles was relatively large. The ratio of the average sizes of the largest and smallest pellets was 3.34 .

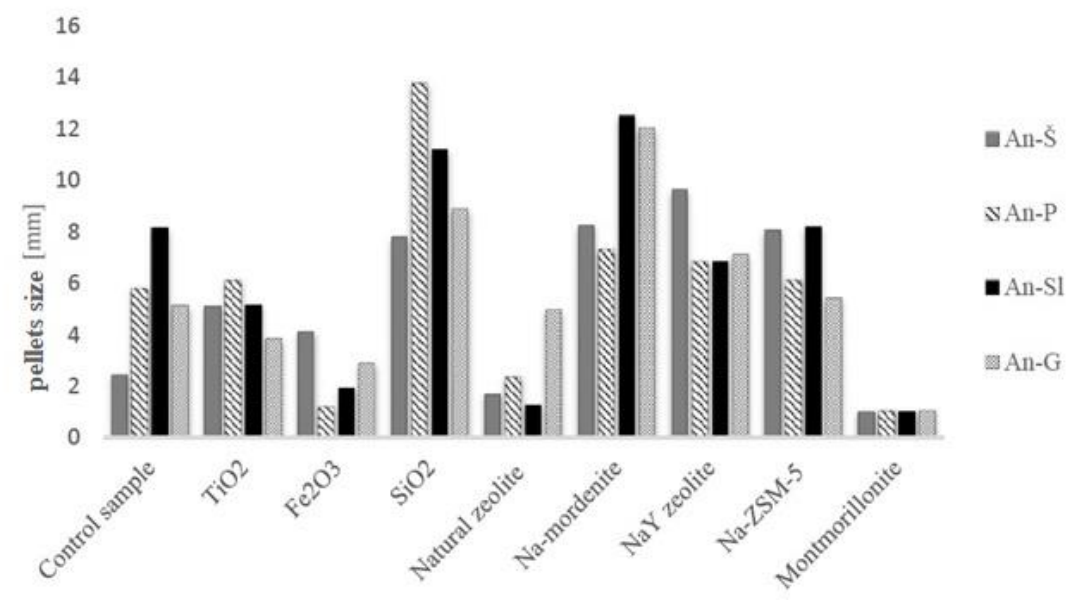

Inorganic substances + Aspergillus niger strains

Fig. 3. Average sizes of pellets [mm] of microscopic filamentous fungi A. niger cultivated with the presence of particles of inorganic substances. 
In the case of pellets acquired by cultivation with the presence of powder substances, this ratio varies from 1.30 to 4.00 . The smallest (the first value) was for pellets acquired with the presence of montmorillonite, the largest (the second value) was for pellets acquired with the presence of iron oxide. With the exception of pellets acquired with the presence of natural zeolite and synthetic iron oxide, these ratios vary in a relatively narrow interval of
1.3 up to 1.76 , of which it seems that this type of substance subdues the original differences observed within the referential group of pellets. A comparison was made between control samples, without inorganic particles, and the samples with these particles present. Pellets acquired from conidia of microscopic filamentous fungi from various locations both experienced enlargements as well as reduction of their diameters (Fig. 4).
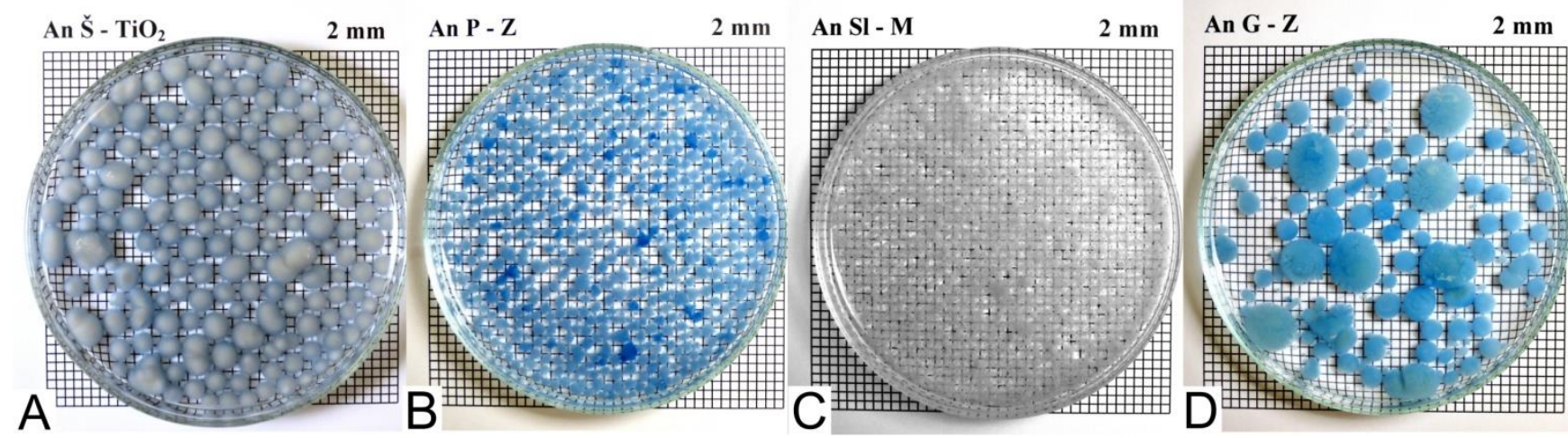

Fig. 4. Shots of pellets of microscopic filamentous fungi A. niger cultivated in an SDB solution with addition of inorganic powders. $\mathbf{A}$ - with addition of $\mathrm{TiO}_{2} ; \mathbf{B}$ - and $\mathbf{D}$ - with addition of zeolite; $\mathbf{C}$ - with addition of montmorillonite. The shots illustrate the significant variance in pellet size due to these substances, e.g. reduction of diameters due to montmorillonite (An $\mathrm{Sl}-\mathrm{M})$ or increase of diameters due to zeolite $(\mathrm{An} G-\mathrm{Z})$. The last figure also documents the differences in the size of the pellets on one Petri dish, i. j. within one strain.

For the comparison of the sizes of microscopic filamentous fungi pellets, the variation of these sizes within one sample of pellets must be taken into consideration. In general, this variation does not exceed one order of magnitude. However, the sizes of the largest and smallest particles do not exceed the ratio $4: 1$. In the case of control samples, this variation was within the interval $2.5-$ $4.5: 1$. In the case of $A n-\breve{S}$ samples cultivated with inorganic particles, the variation of this ratio was 1.3 to $3.0: 1$; in the case of $\mathrm{An}-\mathrm{P}$ samples, 0.86 to $10.0: 1$; in the case of An-G samples, 2.0 to $6.0: 1$ and in the case of $\mathrm{An}-\mathrm{S} 1$ samples, 1.75 to $4.0: 1$. The only $\mathrm{An}-\mathrm{S} / \mathrm{Fe}_{2} \mathrm{O}_{3}$ sample whose ratio was $10: 1$, was the exception compared to the relatively narrow intervals (Tab. 3 ).

Statistical characteristics of the size of Aspergillus niger strains pellets after cultivation with various inorganic substances was presented in Table 3. If the modus and median values of sizes of analyzed pellets are taken into consideration, the following can be said regarding to effect of the aforementioned particles. While clay mineral montmorillonite definitely reduces the size of pellets (Jesenák et al. 2015), regardless of the type of source material, the effect of other inorganic substances was either weak or very differentiated depending on the type of inorganic substance and source location of the strain of microscopic filamentous fungi. Natural zeolite has a similar yet less distinctive effect (Fig. 5).

A great deal of differentiation can be observed in the An - $\breve{S}$ samples, in the case of which most of powders markedly enlarged the size of the pellets. This growth represents two to five times higher modus and median values. The exception was natural zeolite, in addition to the already mentioned montmorillonite, which lowers this value. Samples of $A n-P$ and $A n-G$ strains do not markedly increase these values and in the case of $\mathrm{An}-\mathrm{Sl}$ samples, the size of pellets was mostly reduced. According to many authors (Espinozsa-Ortiz et al. 2017; García-Reyes et al. 2017; Veiter et al. 2018) fungal pellets are spherical, ellipsoidal or oval 
masses of intertwined hyphae with a size usually in the range of several hundred micrometers to several millimeters. Fungal pellets usually appear as a core of densely packed hyphae, surrounded to a large extent by a more annual dispersed or „hairy“ region that contains the radially growing portion of the hyphae (Fig. 5).

The inorganic substances used in the

Table 3. Statistical characteristics of the size of Aspergillus niger strains pellets [mm] after cultivation with various inorganic substances.

\begin{tabular}{|c|c|c|c|c|c|}
\hline & Diameter & Mode & Median & $\begin{array}{c}\text { Variance of sizes of } \\
\text { pellets }\end{array}$ & Number of pellets \\
\hline Fungal strain & \multicolumn{5}{|c|}{$\mathbf{A n}-\check{\mathbf{S}}$} \\
\hline Control sample & 2.44 & 2 & 2 & $2-6$ & 235 \\
\hline $\mathrm{TiO}_{2}$ & 5.12 & 5 & 5 & $4-8$ & 147 \\
\hline $\mathrm{Fe}_{2} \mathrm{O}_{3}$ & 4.11 & 2 & 2 & $2-6$ & 78 \\
\hline $\mathrm{SiO}_{2}$ & 7.80 & 4 & 10 & $4-14$ & 26 \\
\hline Natural zeolite & 1.68 & 1 & 2 & $1-3$ & 742 \\
\hline Na-mordenite & 8.27 & 10 & 9 & $6-10$ & 11 \\
\hline NaY zeolite & 9.62 & 8 & 8 & $8-14$ & 16 \\
\hline Na-ZSM-5 & 8.06 & 8 & 8 & $4-11$ & 15 \\
\hline Montmorillonite & 1.01 & 1 & 1 & $1-2$ & 1,000 \\
\hline Fungal strain & \multicolumn{5}{|c|}{$\mathbf{A n}-\mathbf{P}$} \\
\hline Control sample & 5.82 & 6 & 6 & $2-9$ & 52 \\
\hline $\mathrm{TiO}_{2}$ & 6.11 & 7 & 6 & $3-8$ & 42 \\
\hline $\mathrm{Fe}_{2} \mathrm{O}_{3}$ & 1.21 & 1 & 1 & $1-10$ & 244 \\
\hline $\mathrm{SiO}_{2}$ & 13.75 & 6 & 6 & $6-7$ & 4 \\
\hline Natural zeolite & 2.36 & 2 & 2 & $1-4$ & 404 \\
\hline Na-mordenite & 7.33 & 8 & 8 & $4-10$ & 34 \\
\hline NaY zeolite & 6.85 & 5 & 5 & $5-13$ & 40 \\
\hline Na-ZSM-5 & 6.12 & 6 & 6 & $4-8$ & 49 \\
\hline Montmorillonite & 1.04 & 1 & 1 & $1-2$ & 1,000 \\
\hline Fungal strain & \multicolumn{5}{|c|}{$\mathbf{A n}-\mathbf{S l}$} \\
\hline Control sample & 8.15 & 9 & 85 & $4-10$ & 26 \\
\hline $\mathrm{TiO}_{2}$ & 5.16 & 5 & 5 & $4-7$ & 24 \\
\hline $\mathrm{Fe}_{2} \mathrm{O}_{3}$ & 1.93 & 2 & 2 & $2-8$ & 178 \\
\hline $\mathrm{SiO}_{2}$ & 11.21 & 8 & 10 & $8-14$ & 12 \\
\hline Natural zeolite & 1.27 & 1 & 1 & $1-3$ & 574 \\
\hline Na-mordenite & 12.50 & 10 & 10 & $6-18$ & 12 \\
\hline $\mathrm{NaY}$ zeolite & 6.86 & 4 & 6 & $4-14$ & 42 \\
\hline Na-ZSM-5 & 8.20 & 8 & 8 & $6-12$ & 20 \\
\hline Montmorillonite & 1.04 & 1 & 1 & $1-2$ & 1,000 \\
\hline Fungal strain & \multicolumn{5}{|c|}{ An-G } \\
\hline Control sample & 5.11 & 5 & 5 & $3-8$ & 51 \\
\hline $\mathrm{TiO}_{2}$ & 3.81 & 3 & 4 & $2-12$ & 134 \\
\hline $\mathrm{Fe}_{2} \mathrm{O}_{3}$ & 2.87 & 2 & 2 & $2-10$ & 101 \\
\hline $\mathrm{SiO}_{2}$ & 8.88 & 2 & 7 & $2-10$ & 9 \\
\hline Natural zeolite & 4.96 & 5 & 5 & $2-12$ & 90 \\
\hline Na-mordenite & 12.00 & - & - & $8-28$ & 3 \\
\hline NaY zeolite & 7.10 & 6 & 6 & $5-11$ & 31 \\
\hline Na-ZSM-5 & 5.40 & 5 & 6 & $1-7$ & 5 \\
\hline Montmorillonite & 1.02 & 1 & 1 & $1-2$ & 1,000 \\
\hline
\end{tabular}




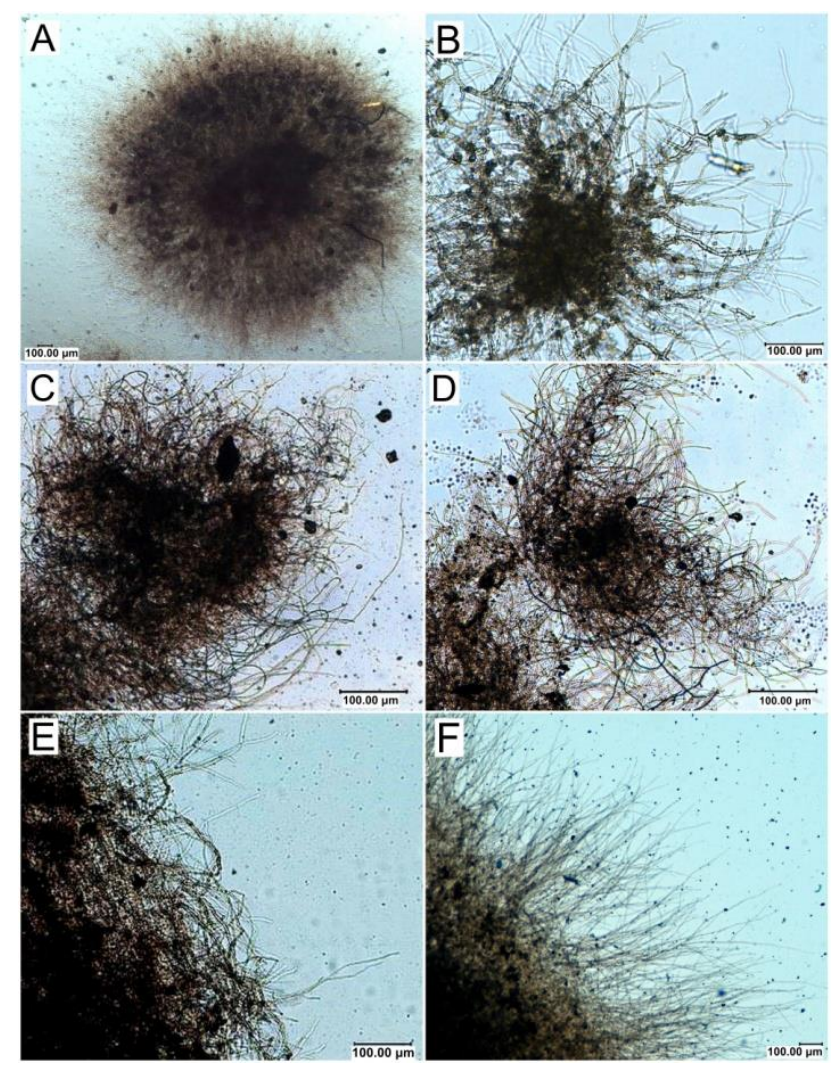

Fig. 5. Pellets of strain $\mathrm{An}-\breve{\mathrm{S}}(\mathbf{A})$ and $\mathrm{An}-\mathrm{G}(\mathbf{B})$ cultivated in addition of montmorillonite, strain $\mathrm{An}-\mathrm{Sl}(\mathbf{C})$ and $\mathrm{An}-\mathrm{P}(\mathbf{D})$ in addition of zeolite and strain $\mathrm{An}-\mathrm{P}(\mathbf{E})$ and $\mathrm{An}-\mathrm{G}(\mathbf{F})$ in addition of $\mathrm{TiO}_{2}$.

aforementioned experiments differ markedly in many characteristics. However, it seems that none of these characteristics plays such a significant role in the creation of these pellets that it would unidirectionally affect their size towards their enlargement or reduction within all four samples of A. niger microscopic filamentous fungi. The only explanation for the exceptional position of clay mineral montmorillonite, which always reduces the size of pellets of microscopic filamentous fungi in all cases to a greater or lesser extent, relates to the size of its mineral particles. As opposed to other inorganic powder substances, montmorillonite particles break down in water solutions into markedly smaller particles (in comparison to the primary size of the particles of other studied substances). Therefore, the reduction of the size of pellets may be a result of spherical limitations in the growth of larger pellets. However, we cannot rule out the possibility that some interphase reactions between the surface of filaments of these fungi and the surface of the clay material particles also play a certain role. This may be related to the ion exchange qualities of montmorillonite. Due to the markedly smaller size of its particles in comparison with zeolites, this effect could be much more distinctive in this case.

\section{Conclusion}

The impact of the presence of water-insoluble inorganic powder additives in cultivation media and suspensions on the final size and morphology of pellets of microscopic filamentous fungus of Aspergillus is complex. Studies seemingly show that the primary role was played by the great differences in the size of the particles of these substances. The degree of spherical obstacles in a cultivation media affected the growth of the fungi. Reduction of the size of these particles enhances various physical and chemical interactions that can contribute to changes in pellet growth. One possibility to determine more precisely the influence of montmorillonite particles size, while preserving its other characteristics, was to study the impact of its various ion exchange forms that may vary markedly. Filamentous fungi play an important role not only in the bio-manufacturing of 
value-added products, but also in bioenergy and environmental research. Production and morphology of fungal pellets depends on complex factors that vary among species, and, therefore, it is not possible to establish a general methodology for the formation of fungal pellets. The use of fungal pellets is very important due to their wide range of applications in bioremediation, biosorption, bioleaching processes or metabolite production.

\section{Acknowledgement}

The research was financially supported by the Slovak National Grant Agency projects VEGA 1/0194/21 and VEGA 1/0658/19.

\section{Conflict of Interest}

The authors declare that they have no conflict of interest.

\section{References}

Čurlík J, Bedrna Z, Hanes J. Holobradý K, Hrtánek B, Kotvas F, Masaryk Š, Paulen J (2003) Pôdna reakcia a jej úprava, 1st Ed. J. Suchoň, Suma print Bratislava, Bratislava, 249 p.

Driouch H, Hansch $\mathrm{R}$, Wucherpfenning $\mathrm{T}$, Rainer $\mathrm{K}$, Witmann Ch (2012) Improved enzyme production by biopellets of Aspergillus niger: Targeted morphology engineering using titanate microparticles. Biotechnol. Bioeng. 109: 462-471.

Espinosa-Ortiz EJ, Rene ER, Guyot F, van Hullebusch ED, Lens PNL (2017) Biomineralization of tellurium and selenium-tellurium nanoparticles by the white-rot fungus Phanerochaete chrysosporium. Int. Biodeterior. Biodegradation. 124: 258-266.

Fawzy EM, Abdel-Motaal FF, El-Zayat SA (2017) Biosorption of heavy metals onto different eco-friendly substrates J. Bioremediat. Biodegrad. 9: 35-44.

Fomina MA, Gadd MG (2002) Influence of clay minerals on the morphology of fungal pellets. Mycol. Res. 106: 107117.

García-Reyes M, Beltrán-Hernández RI, Vázquez-Rodríguez GA, Coronel-Olivares C, Medina-Mporeno SA, JuárezSantillán LF, Lucho-Constantino CA (2017) Formation, morphology and biotechnological applications of filamentous fungal pellets: A review. Rev. Mex. Ing. Quim. 16: 703-720.

Holub M, Balintova M, Demcak S, Hurakova M (2016) Characterization of natural zeolite and determination its adsorption properties. Czas. Inż. Ląd. Śr. Archit. 63: 113-122.

Jesenák K (1994) Laboratory device for sedimentation separation of powders. Ceram.-Silik. 38: 35-36.
Jesenák K, Hlavatý V (2000) Laboratory device for sedimentation of fine bentonite fractions. Scripta Facultatis Scientiarum Naturalium Universitatis Masarykianae Brunensis. 28: 33-36.

Jesenák K, Šimonovičová A, Čerňanský S (2015) Influence of fine-grained montmorillonite on microfungal pellets growth in aqueous suspensions. Nova Biotechnol. Chim. 14: 38-44.

Kapoor A, Viraraghavan T, Culimore RD (1999) Removal of heavy metals using the fungus Aspergillus niger. Bioresour. Technol. 70: 95-104.

Krull R, Wucherpfenning T, Esfandabi EM, Walisko R, Melzer G, Hempel CD, Kempen I (2013) Characterisation an control of fungal morphology for improved production performance in biotechnology. J. Biotechnol. 163: 112113.

Metz B (1976) From pulp to pellet, PhD. Thesis, Delft Technical University of The Netherlands.

Nosalj S, Šimonovičová A (2019) Lipase production of Aspergillus niger wild type strains isolated from different environment. Phytopedon. 18: 15-21.

Ouyang F, Wang, Y, Binqiao R, Zhao L, Song X, Zhang X, Jin Y (2015) Biosorption characteristics of Aspergillus niger spores for removal of $\mathrm{Pb}$ (II) ions from an aqueous solution. In Proceedings of the International Conference on Logistic Engineering, Management and Computer Science, Advances in Intelligent Systems Research. Northeastern University, China.

Papagianni M, Mattey M (2006) Morphological development of Aspergillus niger in submerged citric acid fermentation as a function of the spore inoculum level. Application of neural network and cluster analysis for characterization of mycelial morphology. Microb Cell Fac. 5: 12.

Prajapati SK, Pushpendar K, Anushree M, Poonam $\mathrm{CH}$ (2014) Exploring pellet forming filamentous fungi as tool for harvesting non-flocculating unicellular microalgae. Bioenerg. Res. 7: 1430-1440.

Remenárová M, Takáčová A, Šimonovičová A, Danč L, Nosalj S (2020) Reduction of nickel content from the model solution by consortium of fungal pellets and green algae. In IOP Conference Series: Earth and Environmental Science. $2^{\text {nd }}$ International Conference on Advances in Environmental Engineering, Ostrava.

Shmedider S, Barthel L, Muller H, Meyer V, Breisen H (2019) From three-dimensional morphology to effective diffusivity in filamentous fungal pellets. Biotechnol. Bioeng. 116: 3360-3371.

Šimonovičová A, Hlinková E, Chovanová K (2013) Influence of the environment on the morphological and biochemical characteristics of different Aspergillus niger wild type strains. Indian. J. Microbiol. 53: 187-193.

Šimonovičová A, Kraková L, Pauditšová E, Pangallo D (2019) Occurrence and diversity of cultivable autochthonous microscopic fungi in substrates of old environmental loads from mining activities in Slovakia. Ecotoxicol. Environ. Saf. 172: 194-202.

Šimonovičová A, Kupka D, Nosalj S, Kraková L, Drahovská $\mathrm{H}$, Bártová Z, Vojtková H, Boturová K, Pangallo D (2020) Differences in metabolites production using Biolog 
FF Microplate TM system with and emphasis on some organic acids of Aspergillus niger wild type strains. Biologia: 75: 1537-1546.

Šimonovičová A, Nosalj S, Takáčová A, Mackul'ák T, Jesenák K, Čerňanský S (2017) Responses of Aspergillus niger to selected environmental factors. Nova Biotechnol. Chim. 16: 92-98.

Šimonovičová A, Remenárová $M$, Nosalj S, Takáčová A, Danč L. (2018) Zníženie obsahu niklu z modelového roztoku synergickým účinkom mikroskopickej vláknitej huby a zelenej riasy za statických podmienok. Phytopedon. 18: 1-7.

Teng Y, Xu Y, Wang D (2009) Changes in morphology of Rhizopus chinensis in submerged fermentation and their effect on production of mycelium-bound lipase. Bioprocess. Biosyst. Eng. 32: 397-405.
Veiter L, Rajamanickam V, Herwig CH (2018) The filamentous fungal pellet-relationship between morphology and productivity. Appl. Microbiol. Biotechnol. 102: 2997-3006.

Zahng J, Zhang J (2015) The filamentous fungal pellet and forces driving its formation. Crtical Rev. Biotechnol. 36: 1066-1077.

Znidarsič P, Pavko A (2001) The morphology of filamentous fungi in submerged cultivations as a bioprocess parameter. Morphology of filamentous fungi. Food Technol. Biotechnol. 39: 237-252.

Žemberyová M, Sherman, A, Šimonovičová A, Hagarová I (2010) Bio-accumulation of As (III) and As (V) species from water samples by two strains of Aspergillus niger using hydride generation atomic absorption spectrometry. Int. J. Environ. Anal. Chem. 89: 569-581. 